\title{
David Crystal, Making a Point: The pernickety story of English punctuation
}

\author{
London: Profile Books, 2015
}

\section{Monique Mémet}

\section{OpenEdition}

\section{Journals}

Electronic version

URL: http://journals.openedition.org/asp/4865

DOI: $10.4000 /$ asp. 4865

ISSN: 2108-6354

\section{Publisher}

Groupe d'étude et de recherche en anglais de spécialité

Printed version

Date of publication: 1 November 2016

Number of pages: 151-155

ISSN: 1246-8185

\section{Electronic reference}

Monique Mémet, «David Crystal, Making a Point: The pernickety story of English punctuation », ASp [Online], 70 | 2016, Online since 01 November 2016, connection on 01 November 2020. URL : http:// journals.openedition.org/asp/4865; DOI : https://doi.org/10.4000/asp.4865

This text was automatically generated on 1 November 2020

Tous droits réservés 


\section{David Crystal, Making a Point: The pernickety story of English punctuation}

London: Profile Books, 2015

Monique Mémet

\section{REFERENCES}

Crystal, David. 2015. Making a Point: The pernickety story of English punctuation. London: Profile Books. 378 pp. ISBN 978-1-7812-5350-2. 
David Crystal, a renowned linguist and the author of over 700 books and articles, ${ }^{1}$ published Making a Point: The pernickety story of English punctuation in 2015. After diverse Stories of English (2004, 2011), he chose to relate the story of English punctuation, and to answer the following questions, which he raises in the introduction:

Who were the people who introduced punctuation in the English language? Why did they do it? How did their invention evolve over the centuries? What is happening to punctuation today? And what is its future? (p. xiii)

The answers are given in the thirty-four chapters which make up the book. The first twelve chapters deal with the history of punctuation from "the beginning" (p.1), Anglo-Saxon times, until today, including its usage in electronic media. After a transitional chapter, the next eighteen chapters present a punctuation mark each, starting with what the reader might not have envisaged as one, i.e. word spacing. Two chapters deal with other parts of the language system (capitalisation, layout and typography), and the ways punctuation is used on the Internet. The book concludes with non-prescriptive advice. In addition to these numbered chapters, seventeen "Interludes" illustrate the content of some chapters: facsimiles of book excerpts, such as an extract from NoViolet Bulawayo's We Need New Names (2013) to illustrate “punctuation minimalism" (p. 96), or an excerpt from one of EECummings's ${ }^{2}$ poems to exemplify the use of brackets (pp. 305-306). The book also includes an appendix ("Teaching punctuation"), a theme and author index, as well as a detailed bibliography.

D. Crystal's story of punctuation begins at the time of King Alfred the Great and the first inscriptions on jewels, caskets, and in sermons in the ninth century. The main point of Chapter 1 ("In the beginning ...") is to introduce the angle the author chose to start relating the story of punctuation, i.e. the writing with unspaced text which "came to be a major feature of early Western writing“ (p.4). Before the use of spaces, sentences would have looked like this:

\section{ALFREDMECHEHTGEWYRCAN}

Alfred ordered me to be made (p. 1)

Therapistsneedsspecialtreatment (p. 5)

The point is developed in the second chapter which elaborates on the progressive changes that started before Alfred the Great in England, in the seventh century, when "word-spacing [became] standard practice" (p. 10), even though there were diversity and variability until the eleventh century. D. Crystal underlines the reasons for the changes from "unspaced, punctuationless writing" (p.12) to punctuated texts with word-spaces and ligatures. These changes are linked to the development of "new habits of reading" and the necessity to "remove ambiguity" as well as "the emergence of 
Christianity in the West and the influential views of writers such as St Augustine" (p.12) - St Augustine wrote about the critical role of punctuation in Latin in sacred texts.

From word-spacing, the author moves on to the other changes that took place over the centuries (Chapter 3). The need to identify new sections is one of the steps that gradually gave rise to a sophisticated punctuation system. So several marks were introduced to indicate the beginning of new sections, new lines, as well as the separation of phrases or even syllables in the words. The importance of pauses was indicated with dots (pp. 21-22).

6 In Chapter 4, the importance of reading well is highlighted; punctuation is seen as an aid to oral delivery. Marks were introduced during the Middle English period at the same time as grammar developed. So the main question became: "should punctuation be viewed from a phonetic or a grammatical point of view?" (p. 27).

7 Unsurprisingly, technology brought about modifications (Chapter 5 "The first printer"), and standardised punctuation, in English in particular. D. Crystal compares William Caxton's The Recuyell of the Historyes of Troye printed in 1473 with Norman Blake's Caxton's Own Prose dated 1973, and shows how the use of punctuation differs; for instance, in the modern version all slashes are replaced by periods and spaces are regularised (p. 36).

8 Chapter 6 investigates the terminology used for punctuation; the terms started appearing in books even though they were first used in spoken language, especially among printers (p.37). In the sixteenth century (Chapter 7), two trends altered attitudes towards punctuation: on the one hand, the interest in spelling shown by scholars and, on the other hand, the use of punctuation by playwrights to guide actors. The next step (Chapter 8) was the publishing of pedagogical guides to punctuation in the seventeenth and eighteenth centuries.

9 In Chapter 9, D. Crystal underlines the role that "correctors - we would call them copyeditors today" (p. 71) played from the nineteenth century onwards. The title of Chapter 10, "Passing the buck", conveys the uncertainty in punctuation in the nineteenth century over how to punctuate: "The printers looked to the grammarians for help; and the grammarians looked to the printers" (p. 82).

Chapters 11 and 12 deal with two other perspectives which should be taken into account, semantics and pragmatics. Chapter 11 starts with the recurrent theme of clarity: "Clarity. Making sense. Avoiding ambiguity. These are the words that turn up over and over in books and essays on punctuation" (p. 87). The choice of punctuation marks depends on the meaning writers want to convey; at the same time, punctuation should be "effective." In the twelfth and last chapter of this first section, D. Crystal exemplifies what he dealt with in the tenth chapter, the role of the literary editor; he analyses how Jane Austen's manuscripts, and her punctuation in particular, were modified by literary editors and varied according to the editions.

11 The eighteen chapters devoted to specific punctuation marks all follow a similar pattern: the history of the mark, with variations over time (including the terms to name it); its functions; the most recurrent mistakes which are made when using the marks (for instance the comma splice, p. 204); comparisons with other marks (e.g. "what differentiates the colon from the period and the semicolon", p. 220); and specialised functions (for instance, the colon in computer programs or mathematics, 
p. 223). Each aspect is more or less developed. Two punctuation marks are dealt with in a more elaborate manner because of the numerous questions they have raised over the years: the comma in Chapters 24 "Commas, the big picture", 25 "Commas, the small picture" and 26 "Commas, the serial killer", and the apostrophe in Chapters 28 "Apostrophes: the past," and 29 "Apostrophes: the present (and future)."

Unlike authors of other guides to punctuation such as Eric Partridge (1978 [1953]), ${ }^{3}$ D. Crystal does not start the description of marks with the period (the object of Chapter 16), but with the organisational features of the text (Chapter 14 "Starting at the top"). He includes the layout, the paragraph preferences (Chapter 15), the topics of indention and the drop capital, ${ }^{4}$ to name two.

The researcher will find answers to questions he has often pondered on, such as the use of dashes (Chapter 17 "Devilish dashes"). D. Crystal recalls how the dash came to life:

During the nineteenth century, the terminology of an en $\left.{ }^{5}\right]$ and $e m\left[{ }^{6}\right]$ became established as ways of measuring the amount of printed matter in a line of type. An en was a block of metal type that was the width of the letter $N$; an em was the width of the letter M. (p. 145)

14 He gives the linguistic functions of the dash, and compares it with other marks such as hyphens, double hyphens, commas and round brackets (pp. 146-150).

Chapter 19, wittily entitled "The value of nothing," is a transitional chapter where D. Crystal discusses the disappearance of the period because of poetry and the Internet. ${ }^{7}$

In the following chapters, the author resumes the description of marks with the same structure as in the previous chapters (14 to 16). In Chapter 20 ("Exclamation marks!!"), he provides the reader with a (non-exhaustive) list of the meanings that an exclamation mark can convey. Here are examples: "apology, challenge, agreement, call to action, statement of fact, friendship, argument, hostility [...]" (p. 180).

I am not going to describe the other punctuation marks dealt with, but just mention that they include the ellipsis dots (Chapter 18), question marks (Chapter 21), semicolons and colons (Chapters 22 and 23), commas (Chapters 24, 25 \& 26), hyphens (Chapter 27), apostrophes (Chapters 28 \& 29), round brackets (Chapter 30), and quotation marks (Chapter 31).

18 Throughout the book, D. Crystal also presents marks which are no longer in use: let me cite a few such as the "interrobang," an exclamation mark and a question mark lumped together (pp. 42,186), the inverted exclamation mark (p. 187), or the reversed question mark (p. 194). There are terms which were used by printers and are now employed in word processing, such as the pilcrow (II, a paragraph mark), but these terms are probably not known to most readers.

Chapters 32 and 33 mention the future of punctuation even though recent changes in its use are dealt with all along the book, especially in Chapter 19 mentioned above. The last chapter, entitled "Pragmatic tolerance," underlines the need for pragmatism; according to the author, "punctuation has always been a matter of trends" (p. 344). All in all however, the main aim of punctuation is to be intelligible as "everyone [should] follow an agreed and respected set of norms of usage" (p. 348).

Making a Point makes for fascinating reading; it covers an extremely wide range of topics - I found answers to most of the questions I had about English punctuation. What makes it so pleasant to read is the author's style: it is studded with humorous notes, such as his "Preliminary dialogue." D. Crystal directly addresses the reader from time 
to time in passages such as: "I can imagine a reader thinking with irritation: I know what correlative means, Crystal, you don't have to tell me" (p. 152). The style is neither formal nor really informal; the author pays special attention to transitions between chapters. For instance, to introduce the next chapter on the period, Chapter 15 "Paragraph preferences" ends on: "Why the extra mark when the typography would do the job as well? To answer this, we must turn to the third level of the hierarchy: the period" (p. 133). The work is illustrated with numerous examples of punctuation taken from a multitude of British and American authors or even French ones - Austen, Byron, Bazin, Dahl, Defoe, to name but a few; the examples are also often taken from Crystal's own books.

21 The title of the book is a pun similar to Partridge's (1978 [1953]), a punctuation guide which D. Crystal quotes, and which had been the sole reference for years. However, this new guide is much more than an update of You have a Point There: the organisation, the style and the layout are quite different; they are tackled with in a more reader-friendly manner, and not only because of the choice of the typeface and of the illustrations. Another bestseller about punctuation, Eats, Shoots and Leaves, by Lynne Truss (2003), which the author mentions in the introduction to his book was also very witty, but it did not cover all the punctuation marks, nor did it mention the history of the terms.

The reader might have wished to have had more details about the history of the marks, especially in the first chapters of the book, but he or she can satisfy his or her intellectual curiosity in Crystal's previous writings such as his Encyclopedia of the English Language (1995), or Crystal (2004). There are passages which I would have liked to be able to discuss with the author, especially about students' knowledge of punctuation. He claims that "students in the upper years of a British secondary school (sixteen years of age)" (p. 171) can tell the difference between punctuation in text-messages and in essays, that their essays "showed a perfectly regular use of punctuation" (idem). These conclusions are drawn from the students' documents he analysed. I am not sure the majority of the French academia would find the same results in their students' essays.

I understand the author's choice to use contracted forms; he justifies it himself in the book: "I will or I'll: the meaning is the same, but the effect is different - the second usage is more informal than the first" (p. 88). As an academic, I would have preferred full forms, but the author has obviously targeted a wider audience. I wonder whether this is for the same reason that he uses American syntax from time to time, such as "help convey" (p. 170), or American spelling (e.g. "specialized" [p. 184]). Finally, I suppose that the copy-editor did not spot the following error: "Spacing and layout is erratic" (p. 31).

Those are of course minor details. In conclusion, David Crystal's book is an extremely useful tool for anyone interested in writing proper English, including academics of course. It can be enjoyed either linearly, as a history book, or, thanks to its detailed index, as a reference book. 


\section{BIBLIOGRAPHY}

BILEFSKY, Dan. 2016. “Period. Full Stop. Point. Whatever It's called, It's going out of style.” The New York Times 9 June 2016 retrieved from http://www.nytimes.com/2016/06/10/world/europe/ period-full-stop-point-whatever-its-called-millennials-arent-using-it.html?_r=0, on 11 June 2016. CRYSTAL, David. 1995. The Cambridge Encyclopedia of the English Language. Cambridge: Cambridge University Press.

CRYSTAL, David. 2004. The Stories of English. London: Penguin.

CRYSTAL, David. 2011. English in 100 words. London: Profile Books.

OUDART, Olivier \& Sylvie PRIOUL. 2006. L'art de la ponctuation : le point, la virgule et autres signes fort utiles. Paris: Le Seuil.

PARTRIDGE, Eric. 1978 [1953]. You Have a Point There: A guide to punctuation and its allies. New York: Routledge.

TRUSS, Lynne. 2003. Eats, Shoots \& Leaves: The zero approach tolerance to punctuation. London: Profile Books.

\section{NOTES}

1. http://www.davidcrystal.com/home

2. D. Crystal's spelling

3. The same holds true for guides to French punctuation such as Houdart \& Prioul (2006).

4. Lettrine in French

5. Tiret demi-cadratin in French

6. Tiret cadratin in French

7. A book review in The New York Times - written without any periods at the end of sentences appeared on that topic (Bilefsky 2016).

\section{AUTHORS}

\section{MONIQUE MÉMET}

École normale supérieure de Cachan, m.memet@orange.fr 